\title{
Pengaruh Penggunaan Aditif Kunyit terhadap Bobot Relatif Organ Pencernaan Ayam Kampung Super
}

\author{
Effect of Utilising Turmeric Additive on Relative Weight of Digestive Organs in Super \\ Kampung Chicken
}

\author{
A. Badrussalam, Isroli, dan T. Yudiarti \\ Fakultas Peternakan dan Pertanian Universitas Diponegoro, Semarang \\ Jl. Prof. H. Soedarto, Tembalang, Semarang \\ Corresponding email : ahmadbadrussalam10@gmail.com
}

\begin{abstract}
This research aimed to study utilising turmeric additive on relative weight of digestive organs in super kampung chicken. Research held on $10^{\text {th }}$ November 2017 at Faculty of Animal Husbandry and Agriculture. The chicken used in the research was day old chick (DOC), produced by PT Tirto Hartono, Sleman, Yogyakarta as many as 200 chickens. Experimental design used in this research was Completely Randomised, with 5 treatments and 5 repeatitions, so there were 25 units experiments, every 1 pen contained 8 chickens. The Treatments used were : T0 : Chicken with no turmeric additive, $\mathrm{T} 1=$ Chicken with extract turmeric additive in water $1: 3$, $\mathrm{T} 2=\mathrm{Chickens}$ with flour turmeric additive in ratio of $0.5 \%, \mathrm{~T} 3=$ Chicken with fermented turmeric waste additive in ratio of $0.5 \%, \mathrm{~T} 4=$ Chickens with turmeric waste additive in ratio $0.5 \%$. Observed parameter was weight of digestive organs. If diversity test was significantly different, then next step was Duncan test. The result was showed that giving turmeric additive on relative weight of digestive organ in chicken ratio had a significant effect $(P<0.05)$ on average relative weight of proventriculus but no effect on average relative weight of digestive organ gizzard, heart, duodenum, jejunum, illeum, cecum. Conclusion of this research was by supplementing turmeric additive both mixed feed or water could increase in average relative weight of proventriculus but couldn't increase average relative weight of gizzard, heart, duodenum, jejunum, illeum dan cecum.
\end{abstract}

Key words : chicken, relatif weight of digestive organs.

\begin{abstract}
ABSTRAK
Penelitian bertujuan untuk mengkaji pengaruh penggunaan aditif kunyit terhadap bobot relatif organ pencernaan ayam kampung super.Penelitian dilaksanakan pada tanggal 10 September 2017 sampai 10 November 2017 di Fakultas Peternakan dan Pertanian Universitas Diponegoro. Ayam kampung super yang digunakan dalam penelitian yaitu Day Old Chick (DOC) yang diproduksi oleh PT. Tirto Hartono, Sleman, Yogyakarta sebanyak 200 ekor. Rancangan percobaan yang digunakan dalam penelitian ini adalah rancangan acak lengkap, dengan 5 perlakuan dan 5 ulangan, sehingga ada 25 unit percobaan, setiap 1 pen diisi 8 ekor ayam kampung super. Perlakuan yang digunakan adalah : T0 = Ayam kampung super tanpa diberi aditif kunyit, $\mathrm{T} 1$ = Ayam kampung super diberi aditif perasan air kunyit dalam air minum 1:3, T2 = Ayam kampung super diberi aditif tepung kunyit dalam ransum 0,5\%, T3 = Ayam kampung super diberi aditif fermentasi ampas kunyit dalam ransum $0,5 \%, \mathrm{~T} 4$ = ayam kampung super diberi aditif ampas kunyit dalam ransum $0,5 \%$. Parameter yang diamati adalah bobot relatif organ pencernaan. Apabila uji keragaman berbeda nyata, maka dilanjutkan dengan uji Duncan. Hasil penelitian menunjukkan bahwa pemberian aditif kunyit terhadap bobot relatif organ pencernaan pada ransum ayam kampung super berpengaruh nyata $(\mathrm{P}<0,05)$ pada rataan bobot relatif proventrikulus tetapi tidak berpengaruh nyata pada rataan bobot relatif organ pencernaan gizzard, hati, duodenum, jejunum, ileum dan sekum. Kesimpulan hasil penelitian diperoleh bahwa pemberian aditif kunyit baik dicampur pakan maupun air minum dapat meningkatkan rataan bobot relatif proventrikulus tetapi tidak meningkatkan rataan bobot relatif gizzard, hati, duodenum, jejunum, ileum dan sekum.
\end{abstract}

Kata kunci : ayam kampung super, bobot relatif organ pencernaan.

\section{PENDAHULUAN}

Ayam kampung super merupakan persilangan antara ayam lokal jantan dan ayam ras betina serta merupakan salah satu sumber protein hewani yang potensial. Hal ini ditunjukkan dengan adanya peningkatan konsumsi daging ayam kampung pada tahun 2012-2017 sebesar 0,048 kg/kapita/minggu (BPS, 2018). Peningkatan konsumsi tersebut belum diimbangi dengan peningkatan produktivitas dan biasanya untuk meningkatkannya digunakan 
antibiotik. Namun penggunaannya telah dilarang dan upaya penggantinya salah satunya yaitu kunyit.

Kunyit (Curcuma domestica Val.) adalah salah satu tanaman herbal yang terdapat di Indonesia. Kunyit memiliki kandungan utama dalam rimpang kunyit, yaitu kurkumin, minyak atsiri, resin, oleoresin, desmetoksikurkumin, bidesmetoksikurkumin, lemak, protein, kalsium, fosfor dan besi (Sihombing, 2007). Ekstraks kunyit sudah terbukti dapat mengatasi gangguan pencernaan pada ternak. Penambahan kunyit dalam pakan berfungsi mengoptimalkan pertumbuhan bobot badan, mengoptimalkan bobot relatif organ pencernaan dan meningkatkan kinerja organ pencernaan, yaitu mengeluarkan getah pankreas yang mengandung enzim amilase, lipase dan protease sehingga meningkatkan pencernaan bahan pakan yaitu karbohidrat, lemak dan protein (Nurhayati et al., 2015).

Industri jamu tradisional menghasilkan limbah berupa ampas kunyit. Penggunaan ampas kunyit sebagai aditif pakan untuk ternak dirasa lebih efisien dibandingkan dengan kunyit segar karena tidak harus bersaing dengan manusia serta harga limbah kunyit yang relatif lebih murah sehingga efisien untuk peternak. Ampas kunyit masih mengandung komponen-komponen zat aktif yang masih potensial digunakan sebagai feed additive untuk ayam (Erniasih dan Saraswati, 2006). Kandungan senyawa aktif ampas kunyit sebagian besar masih terikat oleh senyawa-senyawa kompleks yang ada di dalam limbah kunyit sedangkan ternak tidak memiliki kemampuan untuk melepaskan ikatan polimer kompleks, sehingga perlu dilakukan pengolahan untuk melepaskan senyawa kompleks tersebut. Salah satu cara yang dapat dilakukan untuk melepaskan ikatan polimer kompleks tersebut yaitu fermentasi.

Fermentasi merupakan proses perubahan kimia dalam bahan pakan yang disebabkan oleh mikroorganisme atau enzim yang terdapat dalam bahan pakan. Fermentasi dapat merubah rasa bahan/pakan menjadi lebih disukai ternak, perbaikan kualitas menjadi lebih baik dari aspek nutrisi dan daya simpan serta meningkatkan daya cerna sehingga mampu mengoptimalkan pertambahan bobot badan ayam (Frost dan Most, 1987).

Pertambahan bobot badan dipengaruhi oleh perkembangan organ pencernaan, hal ini akan memaksimalkan fungsi sistem pencernaan dan penyerapan nutrisi akan meningkat. Perkembangan organ pencernan ayam berpengaruh terhadap peningkatan bobot relatif organ pencernaan (Susanti, 2015). Bobot relatif berhubungan erat dengan bobot badan, semakin besar bobot relatif organ pencernaan maka semakin banyak nutrien yang dapat dicerna dan diserap sehingga bobot badan meningkat.

Penelitian bertujuan untuk mengkaji pengaruh penggunaan aditif kunyit terhadap bobot relatif organ pencernaan ayam kampung super. Manfaat penelitian adalah dapat memberikan informasi tentang penggunaan aditif kunyit pada peternakan ayam kampung super. Hipotesis penelitian adalah penambahan aditif kunyit dalam ransum ayam kampung super dapat meningkatkan bobot relatif organ pencernaan ayam kampung super.

\section{MATERI DAN METODE}

Penelitian mengenai pengaruh penggunaan aditif kunyit terhadap bobot relatif organ pencernaan ayam kampung super dilaksanakan selama 3 bulan di Fakultas Peternakan dan Pertanian, Universitas Diponegoro, Semarang.

Materi yang digunakan dalam penelitian adalah Day Old Chick (DOC) ayam kampung super yang diproduksi oleh PT. Tirto Hartono, Sleman, Yogyakarta sebanyak 200 ekor. Bahan lain yang digunakan yaitu perasan air kunyit, tepung kunyit, ampas kunyit, fermentasi ampas kunyit.

Kandang yang digunakan adalah kandang pen dan setiap 1 pen diisi 8 ekor ayam kampung super. Setiap 1 pen dilengkapi dengan 1 buah tempat pakan, 1 buah tempat minum (nipple), bohlam 60 watt dan sekam. Kandang yang digunakan adalah jenis litter dengan alas sekam. Peralatan yang digunakan untuk penelitian antara lain petak atau pen sebanyak 12 petak dengan ukuran 100x100 cm, timbangan untuk menimbang ayam dan pakan, thermohygrometer untuk mengukur suhu dan kelembaban dalam dan luar kandang, koran untuk alas kandang saat ayam berumur kurang dari 7 hari, pisau dan gunting untuk carcassing.

\section{Rancangan penelitian}

Rancangan penelitian yang digunakan dalam penelitian ini adalah Rancangan Acak Lengkap, dengan 5 perlakuan dan 5 ulangan, sehingga ada 25 unit percobaan. Perlakuannya adalah :

$\mathrm{T} 0$ = ayam kampung super tanpa diberi aditif kunyit 
$\mathrm{T} 1$ = ayam kampung super diberi aditif air perasan kunyit dalam air minum 1:3

$\mathrm{T} 2$ = ayam kampung super diberi aditif tepung kunyit dalam ransum $0,5 \%$

$\mathrm{T} 3$ = ayam kampung super diberi aditif ampas kunyit fermentasi dalam ransum $0,5 \%$

$\mathrm{T} 4$ = ayam kampung super diberi aditif ampas kunyit dalam ransum $0,5 \%$

Parameter yang diamati adalah bobot relatif proventrikulus, gizzard, hati,duodenum, jejunum, ileum dan sekum pada ayam kampung super.

Kandungan nutrisi kunyit disajikan pada Tabel 1 dan komposisi bahan pakan dan kandungan kimiawi disajikan pada Tabel 2.

Tabel 1. Kandungan Nutrisi Tepung Kunyit, Ampas Kunyit Fermentasi dan Ampas Kunyit

\begin{tabular}{|c|c|c|c|}
\hline Nutrisi Kunyit & $\begin{array}{l}\text { Tepung } \\
\text { Kunyit }\end{array}$ & $\begin{array}{c}\text { Fermentasi } \\
\text { ampas }\end{array}$ & $\begin{array}{l}\text { Ampas } \\
\text { Kunyit }\end{array}$ \\
\hline & \multicolumn{3}{|c|}{------------ $\%$------------ } \\
\hline Protein Kasar & 11,87 & 4,91 & 4,61 \\
\hline Abu & 6,77 & 5,21 & 10,18 \\
\hline Lemak Kasar & 2,89 & 1,01 & 0,21 \\
\hline Serat Kasar & 12,52 & 11,07 & 17,88 \\
\hline Air & 13,42 & 14,82 & 14,26 \\
\hline
\end{tabular}

Sumber: Hasil Analisis Proksimat di Laboratorium Ilmu Nutrisi dan Pakan Fakultas Peternakan dan Pertanian Universitas Diponegoro, 2017.

Tahap pembuatan masing-masing bentukan kunyit dengan bahan dasar kunyit segar. Pembuatan tepung kunyit yaitu kunyit segar dipotong tipis, dikering udara, selanjutnya digiling dan dikeringkan kembali hingga kering selanjutnya diblender agar menghasilkan tepung kunyit yang halus. Pembuatan ampas kunyit yaitu kunyit segar langsung digiling kemudian diperas dan dikering udara, selanjutnya diblender agar menghasilkan ampas kunyit yang halus, untuk pembuatan fermentasi ampas kunyit, langkah awal seperti ampas kunyit ditambah starter yaitu Bacillus sebanyak 10 gram dan air sebanyak 500 ml dihomogenisasi dan diletakkan pada plastik diikat rapat kemudian diletakkan ke dalam ember dan ditutup rapat. Air perasan kunyit dari hasil perasan kunyit untuk pembuatan ampas kunyit dan fermentasi ampas kunyit.
Tabel 2. Komposisi bahan pakan dan kandungan kimiawi

\begin{tabular}{|c|c|}
\hline Nama Bahan & Komposisi (\%) \\
\hline Tepung jagung & 45.5 \\
\hline Tepung biji kedelai & 17.0 \\
\hline Tepung gandum & 10.0 \\
\hline Tepung roti & 5.00 \\
\hline Dedak padi & 4.45 \\
\hline Minyak kelapa sawit & 3.50 \\
\hline Tepung gluten jagung & 3.60 \\
\hline DDGS gandum & 3.00 \\
\hline Meat bone meal & 2.80 \\
\hline Tepung bulu ayam & 2.00 \\
\hline Tepung tulang & 1.50 \\
\hline Lysine & 0.55 \\
\hline Methionine & 0.37 \\
\hline L- threonine & 0,08 \\
\hline Garam & 0.15 \\
\hline Premix & 0.50 \\
\hline \multicolumn{2}{|l|}{ Komposisi kimia : } \\
\hline Energi metabolis $(\mathrm{kcal} / \mathrm{kg})^{2}$ & 3.286 \\
\hline Bahan kering & 91.4 \\
\hline Protein kasar & 19.83 \\
\hline Lemak kasar & 5.40 \\
\hline Serat kasar & 6.20 \\
\hline BETN & 50.01 \\
\hline Air & 80,60 \\
\hline
\end{tabular}

Tahap pelaksanaan dilakukan dengan mengadaptasikan ternak terhadap lingkungan dan pakan perlakuan selama satu minggu serta pemeliharaan selama 60 hari. Pemberian pakan diberikan secara add libitum sesuai dengan kebutuhan ayam kampung super per harinya. Minum diberikan secara terus menerus dengan menggunakan nipple. Kandang dibersihkan seminggu sekali disertai dengan penimbangan bobot ayam per ekor untuk menghitung FCR dan PBBH.

Tahap pengambilan data dilaksanakan saat ayam kampung super berumur 2 bulan dengan kisaran bobot per ekor \pm 700 gram sebanyak 25 ekor sebagai sampel, masing-masing 1 ekor tiap ulangan. Sampel ayam disembelih kemudian dibelah bagian abdomen agar mudah mengambil saluran pencernaannya.

\section{Parameter yang Diamati}

Parameter yang diamati adalah bobot relatif provenrikulus, gizzard, hati, duodenum, jejunum, illeum dan sekum pada ayam kampung super. 


\section{Analisis Data}

Data yang diperoleh dianalisis ragam percobaan perhitungan Rancangan Acak Lengkap (RAL) dengan 5 perlakuan dan tiap ulangan 5 , sehingga ada 25 unit percobaan, setiap 1 pen diisi 8 ekor ayam kampung super. Data yang diperoleh dianalisis menggunakan sidik ragam atau uji $\mathrm{F}$ untuk mengetahui pengaruh perlakuan. Apabila perlakuan berpengaruh nyata maka dilanjutkan dengan Uji Wilayah Ganda (Duncan) pada taraf $5 \%$.

\section{HASIL DAN PEMBAHASAN}

Berdasarkan hasil rataan pada Tabel 3, diketahui bahwa pemberian aditif berbagai bentukan rimpang kunyit pada ransum ayam kampung super berpengaruh nyata $(\mathrm{P}<0,05)$ terhadap bobot relatif proventrikulus (Tabel 3), tetapi tidak berpengaruh nyata terhadap bobot relatif gizzard, hati, duodenum, jejunum, ileum dansekum.

\section{Bobot Relatif Proventrikulus}

Data rataan pada Tabel 3, menunjukkan bahwa pemberian aditif kunyit memberikan pengaruh nyata $(\mathrm{P}<0,05)$ terhadap rataan bobot relatif proventrikulus. Rataan bobot relatif proventrikulus pada perlakuan perasan air kunyit (T1), tepung kunyit (T2) dan ampas kunyit (T4) lebih tinggi dibandingkan dengan tanpa perlakuan (T0) dan fermentasi ampas kunyit (T3). Hal ini sesuai dengan landasan Samadi et al. (2012) bahwa rataan persentase bobot relatif proventrikulus pada ayam adalah 0,44-0,64\% . Rataan bobot relatif proventrikulus yang diberi ampas kunyit (T4) tidak berbeda nyata dengan yang diberi perasan air kunyit (T1) dan yang diberi tepung kunyit (T2), namun berbeda nyata dengan yang diberi fermentasi ampas kunyit (T3) dan tanpa perlakuan (T0). Hal tersebut dikarenakan serat kasar yang terkandung dalam ampas kunyit (T4) dan tepung kunyit (T2) lebih tinggi (Tabel 1), maka kecernaannya sulit untuk dicerna sehingga konsumsi ransum menjadi menurun (Tabel 3), hal ini akan membuat proventrikulus bekerja lebih keras sehingga proventrikulus menjadi tumbuh dan menyebabkan bobot proventrikulus meningkat (Tabel 3). Untuk perasan air kunyit (T1) dikarenakan serat kasarnya rendah (Tabel 3), maka konsumsi aditifkunyit akan meningkat dan membuat konsumsi ransum meningkat, walaupun secara statistik tidak ada perbedaan. Hal tersebut dikarenakan kurkumin yang terkandung di dalam kunyit memiliki khasiat yang dapat mempengaruhi nafsu makan sehingga membuat bobot proventrikulus menjadi meningkat. Proventrikulus mensekresikan enzim pepsin yang merupakan awal dari pencernaan protein agar dapat dipecah menjadi komponen sederhana (peptida dan polipeptida). Menurut Elfandra (2007) bahwa bobot pada proventrikulus mempengaruhi kinerja proventrikulus dalam mensekresikan enzim pepsin yang membantu pencernaan di usus halus, karena menurut Hartono et al. (2016) bahwa peningkatkan aktivitas enzim pencernaan akan menyebabkan vili usus menjadi lebih tinggi dan densitasnya lebih padat sehingga penyerapan nutrient menjadi lebih optimal dengan semakin luas area absorpsi.

\section{Bobot Relatif Gizzard}

Data yang disajikan Tabel 3, menunjukkan bahwa rataan bobot relatif gizzard pada ayam kampung super umur 60 hari tidak dipengaruhi aditif kunyit $(\mathrm{P}>0,05)$ karena aktivitas yang dilakukan gizzard tidak cukup untuk meningkatkan bobot relatif gizzard.

Tabel 3. Rataan bobot relatif organ pencernaan dan konsumsi ransum ayam kampung super umur 60 hari pada berbagai perlakuan

\begin{tabular}{llllll}
\hline \multirow{2}{*}{ Parameter } & \multicolumn{5}{c}{ Perlakuan } \\
\cline { 2 - 6 } & T0 & T1 & T2 & T3 & T4 \\
\hline Proventriklus (\%) & $0,63^{\mathrm{b}}$ & $0,76^{\mathrm{a}}$ & $0,79^{\mathrm{a}}$ & $0,68^{\mathrm{b}}$ & $0,81^{\mathrm{a}}$ \\
Gizzard (\%) & 2,29 & 2,26 & 2,36 & 2,57 & 2,84 \\
Hati (\%) & 2,77 & 2,75 & 2,26 & 2,81 & 2,31 \\
Duodenum (\%) & 0,82 & 0,80 & 1,03 & 0,77 & 0,80 \\
Jejunum (\%) & 1,17 & 1,11 & 1,35 & 1,07 & 1,25 \\
Ileum (\%) & 0,98 & 0,81 & 0,84 & 0,89 & 1,06 \\
Sekum (\%) & 0,72 & 0,49 & 0,68 & 0,52 & 0,83 \\
Konsumsi (g/ekor) & 2525,80 & 2580,00 & 2109,00 & 2327,20 & 2364,20 \\
\hline
\end{tabular}

Superskrip huruf kecil yang berbeda pada baris yang sama menunjukkan berbeda nyata $(\mathrm{P}<0,05)$. 
Menurut Akoso (1993), ukuran gizzard dipengaruhi oleh aktifitasnya. Aktifitas otot gizzard akan terjadi apabila makanan masuk kedalamnya. Saat ransum masuk ke dalam tubuh akan terjadi proses metabolisme. Proses metabolisme ini yang memengaruhi aktifitas gizzard. Menurut pendapat Samadi et al. (2012) bahwa kisaran persentase bobot relatif gizzard pada ayam adalah 1,39-2,32\%. Gizzard merupakan organ pencernaan pada unggas yang biasa disebut perut otot dan memiliki fungsi sebagai pemecah partikel makanan yang berukuran besar menjadi partikel-partikel yang sangat kecil sehingga usus kecil akan lebih mudah melakukan pencernaan. Gizzard berfungsi menggiling atau memecah partikel makanan supaya ukurannya menjadi lebih kecil sehingga memudahkan proses pencernaan dan penyerapan (Pond et al. 1995).

\section{Bobot Relatif Hati}

Berdasarkan rataan pada Tabel 3, menunjukkan bahwa rataan bobot relatif hatipada ayam kampung super umur 60 hari tidak dipengaruhi aditif kunyit $(\mathrm{P}>0,05)$ karena bobot hati dapat berkembang apabila melakukan proses detoksifikasi yang berlebihan. Menurut Maradon et al. (2015), besarnya berat hati disebabkan oleh kerja hati yang semakin berat pada proses detoksifikasi. Menurut Retnani (2009) bahwa bobot relatif hati ayam potong berkisar 2,7-2,9\%. Hati merupakan organ pusat detoksifikasi serta akan mensekresi senyawa-senyawa untuk menetralisir, sehingga akan mengalami hipertropi, prinsip kerja kolekinetik berperan dalam proses biosintesis peningkatan produksi empedu dalam hati akibat terkandungnya sodium kurkuminat yang aktif dalam kurkumin serta efek koleretik ialah peningkatan sekresi empedu dari kantung empedu ke dalam usus halus. Menurut Ressang (1984) bahwa hati berperan dalam sekresi empedu, metabolisme lemak, protein, karbohidrat, zat besi, vitamin, detoksifikasi, pembentukan darah merah dan penyimpanan vitamin.

\section{Bobot Relatif Duodenum, Jejunum dan Illeum}

Data yang disajikan pada Tabel 3, menunjukkan bahwa rataan bobot relatif duodenum pada ayam kampung super umur 60 hari tidak dipengaruhi aditif kunyit $(\mathrm{P}>0,05)$ karena aditif kunyit yang dicampur pakan dan air minum diduga tidak sampai di usus halus. Menurut Solichedi et al. (2003), minyak atsiri yang terkandung dalam kunyit dapat meningkatkan relaksasi usus halus yang berarti mengurangi gerakan peristaltik usus halus, sehingga makanan yang dikonsumsi akan lebih lama tinggal di dalam usus halus. Semakin lama laju pakan maka pencernaan dan absorbsi zat-zat makanan lebih sempurna sehingga meningkatkan bobot relatif usus halus. Menurut Incharoen et al. (2010) bahwa bobot relatif duodenum pada ayam adalah $0,31 \%$. Duodenum adalah bagian pertama usus halus yang melakukan pencernaan dan penyerapan zat makanan dan letaknya sangat dekat dengan dinding tubuh dan terikat pada mesentri yang pendek yaitu mesoduodenum. Menurut Anggorodi (1995) bahwa dinding duodenum akan mensekresikan enzim yang mampu meningkatkan $\mathrm{pH}$ zat makanan yang masuk, sehingga kelarutan dan penyerapan di jejunum dan ileum akan lebih meningkat.

Data rataan pada Tabel 3, menunjukkan bahwa rataan bobot relatif jejunum pada ayam kampung super umur 60 hari tidak dipengaruhi aditif kunyit $(\mathrm{P}>0,05)$ karena aditif kunyit yang dicampur pakan dan air minum diduga tidak sampai di usus halus. Menurut Solichedi et al. (2003), minyak atsiri yang terkandung dalam kunyit dapat meningkatkan relaksasi usus halus yang berarti mengurangi gerakan peristaltik usus halus, sehingga makanan yang dikonsumsi akan lebih lama tinggal di dalam usus halus. Semakin lama laju pakan maka pencernaan dan absorbsi zat-zat makanan lebih sempurna sehingga meningkatkan bobot usus halus. Menurut Incharoen et al. (2010) bahwa bobot relatif jejunum pada ayam adalah $0,52 \%$. Jejunum merupakan bagian dari small intestinum yang paling panjang. Selaput lendir dari small intestinum memiliki jonjotyang lembut dan menonjol seperti jari. Menurut Anggorodi (1995) bahwa jejunum memiliki fungsi sebagai penggerak aliran pakan dalam usus dan juga untuk menaikkan permukaan penyerapan sari makanan.

Berdasarkan rataan pada Tabel 3, menunjukkan bahwa rataan bobot relatif ileum pada ayam kampung super umur 60 hari tidak dipengaruhi aditif kunyit $(\mathrm{P}>0,05)$ karena aditif kunyit yang dicampur pakan dan air minum diduga tidak sampai di usus halus. Menurut Solichedi et al. (2003), minyak atsiri yang terkandung dalam kunyit dapat meningkatkan relaksasi usus halus yang berarti mengurangi gerakan peristaltik usus halus, sehingga makanan yang dikonsumsi akan lebih lama tinggal di dalam usus halus. Semakin lama laju pakan maka 
pencernaan dan absorbsi zat-zat makanan lebih sempurna sehingga meningkatkan bobot usus halus terhadap perlakuan yang diberikan. Menurut Incharoen et al. (2010) bahwa bobot relatif ileum adalah $0,42 \%$. Ileum merupakan segmen usus halus yang rentangannya adalah dari Meckel's diverticulum sampai dengan awal percabangan sekum. Menurut Siagian (2016) bahwa Ileum merupakan bagian paling ujung dari usus halus berfungsi dalam proses penyerapan nutrisi dikarenakan penyerapan nutrisi terbesar terjadi dalam ileum, ileum memiliki peranan mengabsorbsi nutrisi seperti asam amino, vitamin dan monosakarida.

\section{Bobot Relatif Sekum}

Data rataan pada Tabel 3, menunjukkan bahwa rataan bobot relatif sekum pada ayam kampung super umur 60 hari tidak dipengaruhi aditif kunyit $(\mathrm{P}>0,05)$ karena sekum akan tumbuh apabila serat kasar ransum tersebut tinggi. Menurut Utami (2012), sekum berfungsi sebagai tempat pencernaan serat kasar dan penyerapan air. Kandungan serat kasar pada ransum masih bisa dicerna dengan baik oleh organ gizzard sebelum sampai pada sekum. Menurut Samadi et al. (2012) bahwa rataan persentase bobot relatif Sekum pada ayam adalah berkisar 0,29-0,41\% . Sekum berfungsi dalam membantu penyerapan air, pencernaan karbohidrat, protein dan serat kasar dengan bantuan bakteri yang hidup di dalamnya. Menurut Grist (2006) bahwa sekum selain dapat membantu penyerapan air, pencernaan karbohidrat, protein dan serat dapat pula berfungsi memecah selulosa dengan bantuan mikroorganisme, mensintesa vitamin, dan sekresi hormon.

\section{KESIMPULAN}

Berdasarkan hasil penelitian diperoleh bahwa pemberian aditif kunyit baik dicampur pakan maupun air minumdapat meningkatkan rataan bobot relatif proventrikulus tetapi tidak meningkatkan rataan bobot relatif gizzard, hati, duodenum, jejunum, ileum dan sekum. Ayam kampung super dapat diberi aditif kunyit dalam ransum maupun air minum untuk meningkatkan bobot relatif organ pencernaan.

\section{DAFTAR PUSTAKA}

Akoso, T. 1993. Kesehatan Unggas Panduan bagi Petugas Teknis, Penyuluhan, dan Peternak. Kanisius. Yogyakarta.
Badan Pusat Statistik. 2018. Rata-Rata Konsumsi Per Kapita Seminggu Beberapa Macam Bahan Makanan Penting Tahun 20072017: Badan Pusat Statistik Kota Jakarta.

Elfandra. 2007. Pemberian Warna Lampu Penerangan yang Berbeda terhadap Organ Dalam Ayam Broiler. Fakultas Peternakan, Institut Pertanian Bogor. (Skripsi Sarjana Peternakan)

Erniasih, I. dan T. R. Saraswati. 2006. Penambahan limbah padat kunyit (Curcuma domestica) pada ransum ayam dan pengaruhnya terhadap status darah dan hepar ayam (Gallus sp). Buletin Anatomi dan Fisiologi. 14 (2): 1 - 6.

Frost, G. M and D. A. Most. 1987. Production of Enzyme by fermentation. In Biotechnology, Vol. 7a, J. F. Kennedy, (ed) Verlag Chemie, Weinheim, pp. 65211 .

Grist, A. 2006. Poultry Inspection. Anatomy, Physiology, and Disease Conditions. $2^{\text {nd }}$ Edition. Nottingham University Press, United Kingdom.

Hartono, E. F., N. Irianti dan S. Suhermiyati. 2016. Efek penggunaan sinbiotik terhadap kondisi miklofora dan histologi usus ayam sentul jantan. J. Agripet. 16 (2): 97-105.

Incharoen, T., K. Yamauchi, T. Erikawa and H. Goto. 2010. Histology of intestinal villi and epithelial cells in chicken fed low crude protein or low crude fat diets. Italian Journal of Animal Science 9: 429434.

Maradon, G.G., R. Sutrisna dan Erwanto. 2015. Pengaruh ransum dengan kadar serat kasar berbeda terhadap organ dalam ayam jantan tipe medium umur 8 minggu. J. Ilmu Peternakan Terpadu 3 (2): 6-11.

Nurhayati, Wirawati, dan D. D. Putri. 2015. Penggunaan produk fermentasi dan kunyit dalam pakan terhadap performan ayam pedaging dan Income over feed and chick cost. J. Zootek. 35 (2): 379-389. 
Pond, W. G., D. C. Church, and K. R. Pond, 1995. Basic Animal Nutrition and Feeding.Fourth edition. John Wiley \& Sons, New York.

Ressang, A.A. 1984. Patologi Khusus Veteriner. Edisi ke-2. Percetakan Bali, Bali.

Retnani, Y., E. Suprapti, I. Firmansyah, L. Herawati dan R. Mutia. Pengaruh penambahan zat pewarna dalam ransum ayam broiler terhadap penampilan, persentase berat bursa fabrisius, karkas dan organ dalam. JITAA. 34 (2): 115121.

Samadi, S., M. Delima, Z. Hanum dan M. Akmal. 2012. Pengaruh level substisusi protein sel tunggal $(\mathrm{Cj}$ prosin) pada pakan komersial terhadap performan ayam broiler. J. Agripet. 12 (1): 7-15.

Siagian, Y. A. 2016. Gambaran Histologis dan Tinggi Vili Usus Halus Bagian Ileum Ayam Ras Pedaging yang Diberi Tepung Daun Kelor (Moringa oleifera) dalam Ransum. Fakultas Peternakan, Universitas Hasanuddin. (Skripsi Sarjana Peternakan).
Sihombing, A. F. 2007. Aplikasi Ekstrak Kunyit (Curcuma domestica) sebagai Bahan Pengawet Mie Basah. Fakultas Teknologi Pertanian, Institut Pertanian Bogor. (Skripsi Sarjana Teknologi Pertanian).

Solichedi, K., U. Atmomarsono dan V. D. Yunianto. 2003. Pemanfaatan kunyit (Curcuma domestica Val) dalam ransum broiler sebagai upaya menurunkan lemak abdominal dan kadar kolestrol darah. JITAA. $\quad 28(3): 172-178$.

Susanti, M. 2015. Penggunaan Pollard Berprobiotik dalam Ransum terhadap Pertumbuhan Saluran Pencernaan Ayam Kampung Super. Fakultas Peternakan dan Pertanian, Universitas Diponegoro. (Skripsi Sarjana Peternakan).

Utami, D. D. 2012. Pengaruh Pemberian Daun Teh Tua dalam Ransum Sebagai Aditif Pakan terhadap Karkas dan Ukuran Organ Visceral Ayam Broiler Jantan. Fakultas Pertanian, Universitas Sebelas Maret. (Skripsi Sarjana Peternakan). 